\title{
Hematological profile of East African short-horn zebu calves from birth to 51 weeks of age
}

\author{
I. Conradie van Wyk • A. Goddard • \\ B. M. de C. Bronsvoort • J. A. W. Coetzer • C. Booth • \\ O. Hanotte • A. Jennings $\cdot$ H. Kiara $・$ P. Mashego • \\ C. Muller • G. Pretorius • E. J. Poole • S. M. Thumbi • \\ P. G. Toye • M. E. J. Woolhouse • B. L. Penzhorn
}

Received: 14 March 2012 / Accepted: 14 May 2012 /Published online: 1 June 2012

(C) Springer-Verlag London Limited 2012

\begin{abstract}
This paper is the first attempt to accurately describe the hematological parameters for any African breed of cattle, by capturing the changes in these parameters over the first 12 months of an animal's life using a populationbased sample of calves reared under field conditions and natural disease challenge. Using a longitudinal study design, a stratified clustered random sample of newborn calves was recruited into the IDEAL study and monitored at 5-weekly intervals until 51 weeks of age. The blood cell analysis
\end{abstract}

I. C. van Wyk $(\bowtie) \cdot$ J. A. W. Coetzer • B. L. Penzhorn

Department of Veterinary Tropical Diseases,

Faculty of Veterinary Science, University of Pretoria,

Private Bag X4, Onderstepoort,

Pretoria 0110, South Africa

e-mail: ilana@conradie.net

A. Goddard $\cdot$ C. Booth $\cdot$ P. Mashego $\cdot$ C. Muller $\cdot$ G. Pretorius Clinical Pathology, Department Companion Animal Medicine, Faculty of Veterinary Science, University of Pretoria, Private Bag X4, Onderstepoort,

Pretoria 0110, South Africa

B. M. de C. Bronsvoort • A. Jennings

The Roslin Institute, University of Edinburgh,

Easter Bush,

EH25 9RG, Edinburgh, UK

\section{O. Hanotte}

School of Biology, University of Nottingham,

Nottingham NG7 2RD, UK

H. Kiara $\cdot$ E. J. Poole $\cdot$ P. G. Toye

International Livestock Research Institute,

P.O. Box 30709-00100, Nairobi, Kenya

S. M. Thumbi • M. E. J. Woolhouse

Centre for Immunology, Infection \& Evolution,

University of Edinburgh,

Edinburgh EH9 3JT, UK performed at each visit included: packed cell volume; red cell count; red cell distribution width; mean corpuscular volume; mean corpuscular hemoglobin concentration; hemoglobin concentration; white cell count; absolute lymphocyte, eosinophil, monocyte, and neutrophil counts; platelet count; mean platelet volume; and total serum protein. The most significant age-related change in the red cell parameters was a rise in red cell count and hemoglobin concentration during the neonatal period. This is in contrast to what is reported for other ruminants, including European cattle breeds where the neonatal period is marked by a fall in the red cell parameters. There is a need to establish breedspecific reference ranges for blood parameters for indigenous cattle breeds. The possible role of the postnatal rise in the red cell parameters in the adaptability to environmental constraints and innate disease resistance warrants further research into the dynamics of blood cell parameters of these breeds.

Keywords Hematology · East African · Zebu · Calves · Longitudinal study

\section{Introduction}

The sedentary mixed crop-livestock smallholding system encompasses $>50 \%$ of poor people resident in East Africa. These resource-poor subsistence farmers own only a few animals, yet these animals are one of their principal capital assets. Subsistence farmers rely on livestock for food security, financial income, and social welfare. Indigenous breeds are regionally very important and constitute up to $77 \%$ of the total Kenyan cattle population (Rege et al. 2001). The small East African short-horn zebu, in particular, is the most 
common breed in eastern and parts of south-central Africa (Mwacharo et al. 2006). Indigenous breeds are preferred by farmers for their adaptability in terms of disease resistance, heat tolerance, and water and food requirements (Mwacharo and Drucker 2005). Cattle are used for animal traction, milk and meat, and the dung for fertilizer (Rege et al. 2001).

The tropical climate in western Kenya is conducive for the survival of many infectious pathogens and vectors. The most economically important diseases of livestock in subSaharan Africa are tick-borne diseases [East Coast fever (ECF), heartwater, anaplasmosis, and babesiosis], trypanosomiasis (Uilenberg 1995; Minjauw and McLeod 2003; Maudlin 2006), and helminthiasis. Smallholder farmers are particularly vulnerable to the economic impact of infectious diseases of livestock. Generally tick-borne infections do not affect trade in livestock, but they are a significant cause of production losses (Perry and Young 1995). Losses include lowered production rates, mortalities, decreased reproduction rates, and costs of treatment and control measures. These diseases also indirectly constrain livestock production through limiting the use of the highly susceptible improved breeds of livestock that are used in other countries to improve livestock productivity (Perry and Young 1995).

Baseline values of the parameters that can be used to measure an animal's health status, including hematological parameters, are lacking for indigenous cattle breeds. Most published reference ranges for these parameters for cattle were compiled for European breeds (Jain 1993; Knowles et al. 2000; Mohri et al. 2007). Studies have indicated that baseline values for hematological parameters differ between the various cattle breeds in the tropics (Oduye and Okunaiya 1971). The aim of this study was to investigate the hematological profile of East African short-horn zebu cattle living in tropical field conditions in Western Kenya, in particular the age-related changes in the blood parameters from neonate to 51 weeks. This paper is the first attempt to accurately describe the hematological parameters for any African cattle breed capturing the changes in these parameters over the first 12 months of an animal's life using a population-based sample of calves reared in their natural environment and disease challenges.

\section{Materials and methods}

The study was set in Busia district, Western Kenya (Fig. 1). This site was considered to represent smallholder livestock farming systems in East Africa. The climate is tropical, and the main land use in the area is mixed crop/livestock farming. The main crops cultivated include maize, sugarcane, cotton, pigeon peas, and sisal. The main cattle breed kept is the indigenous zebu, of which the majority are East African short-horn zebus. These short-horn zebus are a

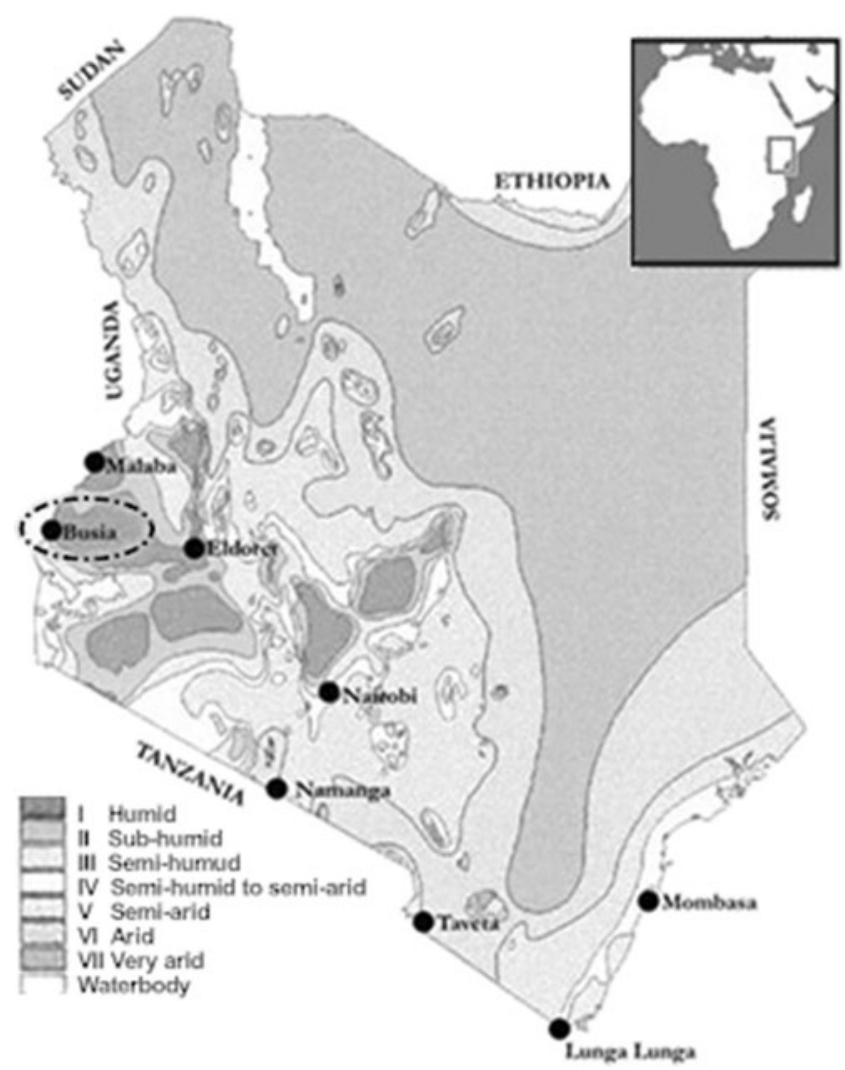

Fig. 1 Map of Kenya showing agroclimatic zones and highlighting the study area, Busia [adapted from map source: www.fao.org/docrep/008/ y5968e/y5968e10.htm (2005)]

relatively small breed but are considered to be well adapted to the local environmental constraints (Fig. 2). The calves recruited into the study remained with their herd of origin, and were exposed to the natural pathogen challenge in the field. For the duration of the study, no interventions in terms of prevention or treatment (except on welfare grounds in

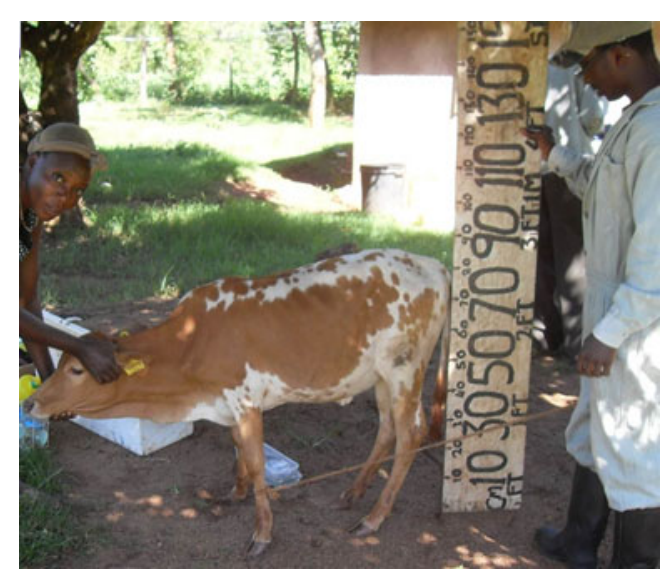

Fig. 2 An East African short-horn zebu calf at 51 weeks of age (69 kg body mass) 
which case calves were censored) against infection were practiced.

A stratified two-stage cluster sampling strategy was used. Stratification was by agroecological zone (Jaetzold and Schmidt 1983) with first-stage cluster (sublocation) selected using stratified random sampling with replacement and second-stage cluster (calf) selected using ordinary random sampling without replacement. A total of 548 calves from sedentary mixed crop-livestock smallholding farms were recruited between October 2007 and September 2009. Calves were recruited within 7 days of birth and monitored routinely at 5-weekly intervals until 51 weeks of age. At each visit a complete clinical examination of the calf was performed and relevant samples collected. These samples included thin and thick peripheral smears of blood collected from the marginal ear vein, jugular blood in 10-ml plain vacutainer tube for the separation of serum, and jugular blood for hematology in 5-ml ethylenediaminetetraacetic acid (EDTA) plastic tubes.

Initial sample processing and analysis occurred at the local field laboratory, Busia, Kenya. Packed cell volume (PCV) was measured manually using a Hawksley microhematocrit reader (Jain 1993). Automated blood cell analysis was performed using the pocH-100iV Diff (Sysmex (C) Europe GMBH). The hematological parameters investigated included: red cell count (RCC), hemoglobin concentration (HGB), mean corpuscular volume (MCV), mean corpuscular hemoglobin concentration (MCHC), red cell distribution width (RDW), total white cell count (WCC), platelet count (Plt), and mean platelet volume (MPV). Total serum protein (TSP) was measured from $100 \mu \mathrm{L}$ serum using a refractometer (model RHC-200ATC, Westover Scientific).

In addition to the automated blood analysis, thin blood smears were made from EDTA blood for manual differential cell counts. These smears were transported to the University of Pretoria, South Africa, where blood smears were stained with Diff Quick (Kyron, South Africa) for differential counts to calculate the absolute lymphocyte count (Lymph), absolute eosinophil count (Eos), absolute neutrophil count (Neut), and absolute monocyte count (Mono).

Descriptive statistics (mean and $95 \%$ confidence intervals) were used to describe the variation and spread in each hematological parameter of the calf population at each sampling point. Graphs are used to illustrate the changes in each parameter over time. The computation of the results and the production of the graphs were done with $\mathrm{R}$ 2.8.1 (Ihaka and Gentleman 1996).

\section{Results}

Figures 3, 4, 5, 6, 7, 8, 9, 10, 11, 12, and 13 illustrate the changes for all parameters for the total calf population between days 7 and 364. The calves showed a significant increase in $\mathrm{PCV}, \mathrm{RCC}$, and $\mathrm{HGB}$ from days 7 (means of $30 \%, 7.73 \times 10^{6} / \mu \mathrm{L}$ and $10 \mathrm{~g} / \mathrm{dL}$, respectively) to 42 (means of $36 \%, 10.23 \times 10^{6} / \mu \mathrm{L}$ and $12 \mathrm{~g} / \mathrm{dL}$; Figs. 3, 4, and 5). From day 42, the general trend for all three parameters was a decrease until day 364 . The RDW was relatively high between days 7 and 42 (means of 34.9 and $35.9 \mathrm{fL}$, respectively), indicating a significant variation in the size of red blood cells, which is suggestive of a high number of immature red blood cells (Fig. 6). From days 42 to 112 , the RDW decreased significantly, and then it remained between 31.2 and $31.8 \mathrm{fL}$ to day 364. The MCV (Fig. 7) was relatively high at day 7 (mean $39.8 \mathrm{fL}$ ), confirming the presence of a high number of immature red blood cells, but decreased gradually from days 7 up to 147 (mean $33.6 \mathrm{fL})$, from where it increased gradually until day 364 (mean 36.0 fL). The MCHC (Fig. 8) showed a similar but more gradual trend, where it decreased between days 7 (mean $32.2 \mathrm{~g} / \mathrm{dL}$ ) and 77 (mean $31.6 \mathrm{~g} / \mathrm{dL}$ ), and then increased up to day 364 (mean $33.05 \mathrm{~g} / \mathrm{dL})$.

The WCC and Lymph (Figs. 9 and 10) showed very gradual increases from days 7 (mean $9.00 \times 10^{3} / \mu \mathrm{L}$ and $3.7 \times 10^{3} / \mu \mathrm{L}$ ) to 364 (mean $11.40 \times 10^{3} / \mu \mathrm{L}$ and $7.6 \times 10^{3} / \mu \mathrm{L}$ ). The Eos (Fig. 11) increased considerably from days 7 (mean $\left.0.27 \times 10^{3} / \mu \mathrm{L}\right)$ to $322\left(\right.$ mean $\left.0.75 \times 10^{3} / \mu \mathrm{L}\right)$. The Neut showed a gradual decrease from days 7 to 112 , after which it remained between 2.4 and $2.55 \times 10^{3} / \mu \mathrm{L}$ (mean) until day 287 and increased again on day 364 .

The Plt (Fig. 12) also showed a steady decrease from day 7 (mean $611 \times 10^{3} / \mu \mathrm{L}$ ) up to day 364 (mean $385.5 \times$ $10^{3} / \mu \mathrm{L}$ ). The MPV was relatively high at day 7 (mean $6.5 \mathrm{fL}$ ), decreased gradually up to day 112 (mean $5.8 \mathrm{fL}$ ), and increased up to day 364 (mean $6.2 \mathrm{fL}$ ). The TSP (Fig. 13) was relatively high at day 7 (mean $9.8 \mathrm{~g} / \mathrm{dL}$ ), after which it decreased up to day 112 (mean $7.6 \mathrm{~g} / \mathrm{dL}$ ) but then remained between 7.6 and $8.0 \mathrm{~g} / \mathrm{dL}$ (mean) up to day 364.

\section{Discussion}

This study showed that the hematological profile of the short-horn zebu differed both in levels and age-related trends compared to reference ranges reported for European breeds. For comparison, reported ranges for PCV for other indigenous cattle breeds are depicted in Table 1 and for European breed in Table 2, for which age-related changes are reported in more detail.

The most significant age-related changes in the red blood cell parameters of the short-horn zebu calves in this study occurred between days 7 and 112. Concurrent 
Fig. 3 Age-related changes in mean $(95 \% \mathrm{CI}) \mathrm{PCV}$ of East African short-horn zebu calves from birth to 51 weeks of age $(n=548)$

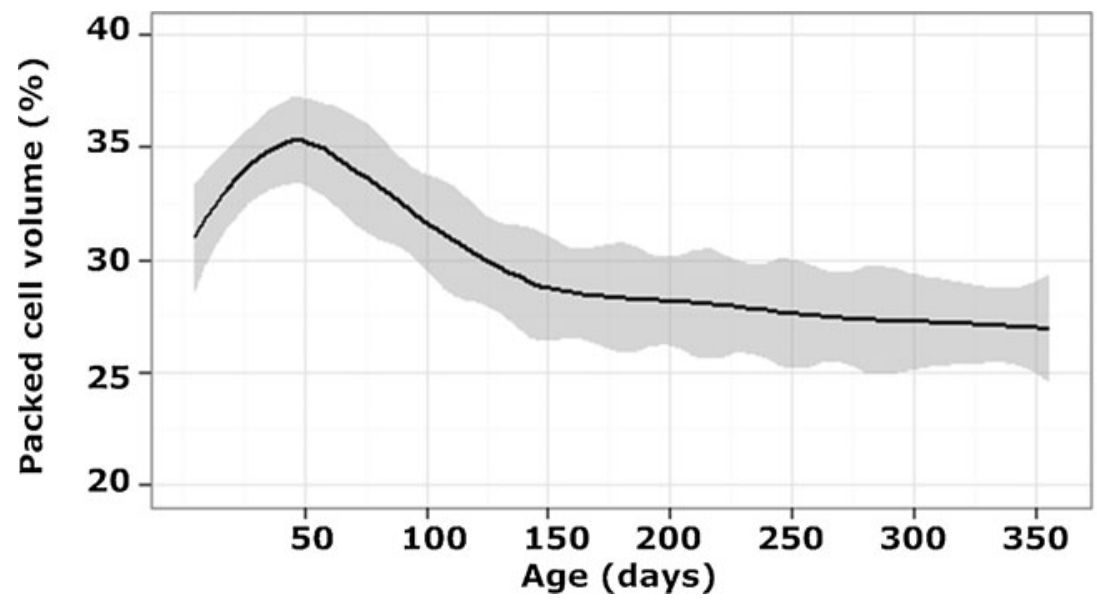

low RCC and PCV with a relatively high MCV and RDW in the first week suggest a macrocytic anemia. A high RDW value is an indication of anisocytosis which is often seen in regenerative responses due to a high number of reticulocytes. Following days 7 up to 42, there was a significant increase in PCV, HGB, and RCC accompanied by a high RDW, suggestive of increased erythropoiesis. The high MCV and a concurrent decrease in MCHC seen between days 7 and 42 also indicate an increase in the number of immature $\mathrm{RBC}$ which is indicative of increased erythropoiesis. In neonatal Holstein calves, erythrocytes were found to decrease in size up to the age of 3-4 months (Mohri et al. 2007), resulting in a gradual decrease in MCV. Immature red blood cells do not yet produce hemoglobin optimally, since hemoglobin production per cell increases as red blood cells mature (Harvey 1989), hence a lower MCHC.

After day 42, there was a decrease in PCV and HGB together with a continuing decrease in MCV and MCHC, while RCC started decreasing from day 77 . This may be suggestive of the development of microcytic hypochromic anemia. Iron supplementation during the first 4 weeks after birth corrected the drop in HGB in dairy calves (Mohri et al.

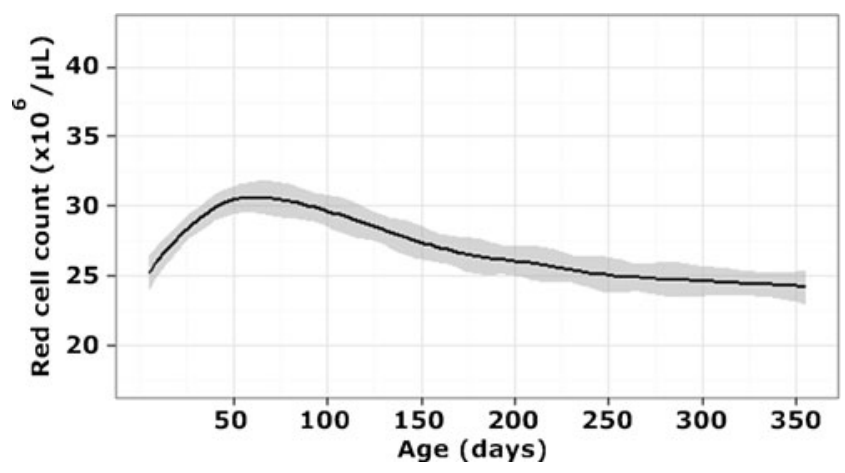

Fig. 4 Age-related changes in the mean (95\% CI) RCC of East African short-horn zebu calves from birth to 51 weeks of age $(n=548)$
2004). The iron levels of calf serum were not evaluated in this study but could possibly have added value to explaining the results in this study.

The relatively low numbers of WCC and Lymph and high Neut around birth are consistent with what is reported for other cattle breeds (Knowles et al. 2000; Mohri et al. 2007) and are due to perinatal stress and high levels of cortisol during partus (Jain 1993). After the first week, levels in WCC, Lymph, and Eos increased as the immune system matured and the animals became exposed to pathogens with resultant cellular immune responses. The Eos and Mono of the short-horn zebu were considerably higher than published ranges for neonatal calves of European breeds (Knowles et al. 2000; Mohri et al. 2007), but are comparable to ranges reported for other indigenous African cattle breeds (Oduye and Okunaiya 1971) and are possibly related to high parasite burdens under field conditions.

The platelet counts of the short-horn zebus were relatively high at day 7 and then decreased significantly up to day 364. The MPV was also relatively high at week 1. Together with a high RDW at day 7, this is suggestive of a regenerative response by the bone

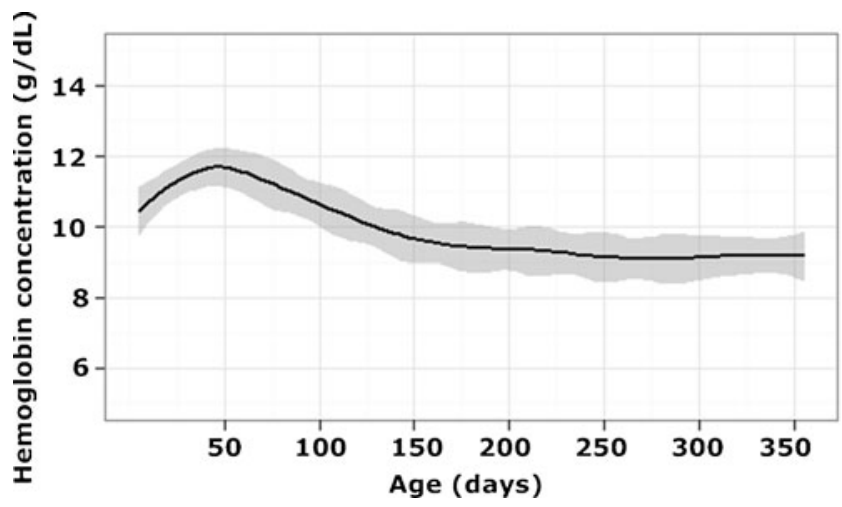

Fig. 5 Age-related changes in mean $(95 \%$ CI) HGB of East African short-horn zebu calves from birth to 51 weeks of age $(n=548)$ 


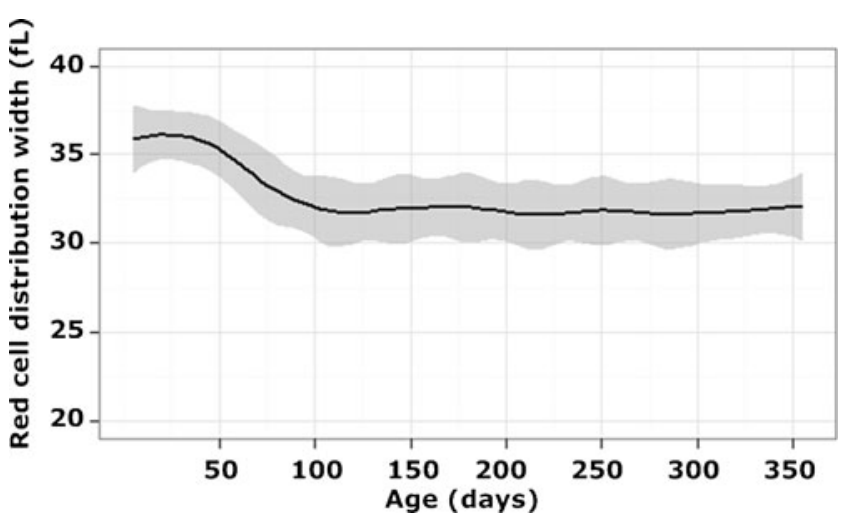

Fig. 6 Age-related changes in mean $(95 \% \mathrm{CI}) \mathrm{RDW}$ of East African short-horn zebu calves from birth to 51 weeks of age $(n=548)$

marrow at the time around birth in both red cells and platelets.

The initial high levels in TSP in the first week were likely due to the uptake of immunoglobulins from colostrum. The degradation of absorbed immunoglobulins likely contributed to the age-related decrease in TSP after the first week. Chronic parasitic infections, such as severe helminthiasis, or malnutrition or a combination of both could possibly also have contributed to the gradual decrease in TSP after day 7 .

The increase found in the red cell parameters during the neonatal period in the short-horn zebu calves in this study is in contrast to what is described for other ruminants, including European cattle breeds (Karesh et al. 1986; Knowles et al. 2000; Mohri et al. 2007). For these species and breeds, there is a significant decrease in PCV, HGB, and MCV in neonates up to around 6 weeks that coincides with an increase in RCC, after which all three parameters increase up to adult levels (Karesh et al. 1986; Knowles et al. 2000; Mohri et al. 2007, Table 2). These changes, which are considered physiological, are ascribed to a decline in fetal erythrocytes at a faster rate than the production of adult-type erythrocytes (Karesh et al. 1986). This also coincides with

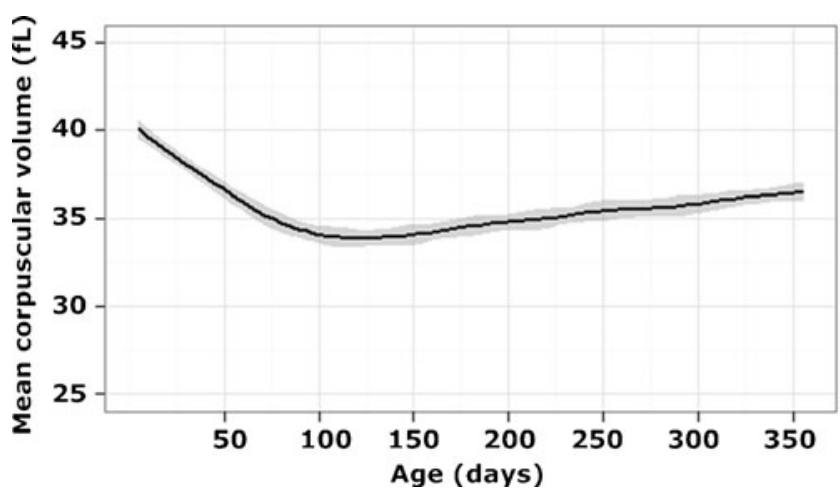

Fig. 7 Age-related changes in mean $(95 \% \mathrm{CI}) \mathrm{MCV}$ of East African short-horn zebu calves from birth to 51 weeks of age $(n=548)$

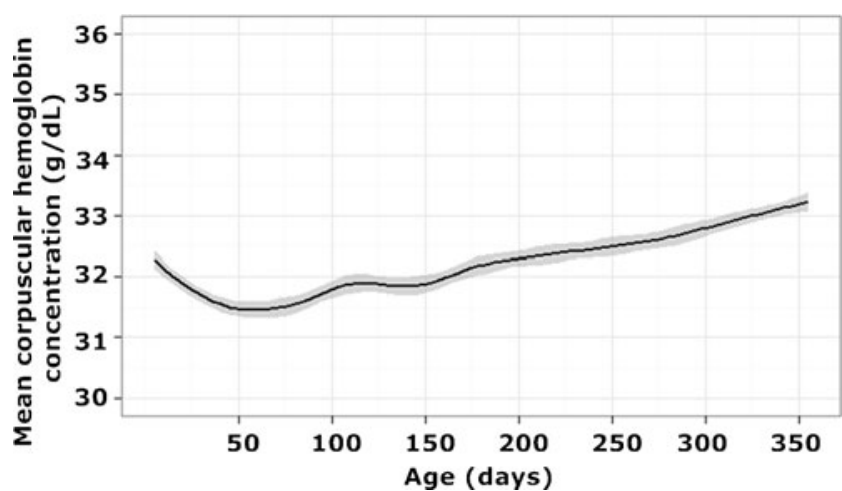

Fig. 8 Age-related changes in mean $(95 \% \mathrm{CI}) \mathrm{MCHC}$ of East African short-horn zebu calves from birth to 51 weeks of age $(n=548)$

the replacement of fetal hemoglobin by adult hemoglobin (Jain 1993; Mohri et al. 2007). Ruminants and primates have a distinct type of hemoglobin during fetal life (Jain 1993). In these species embryonal hemoglobin is soon replaced by fetal hemoglobin ( $\mathrm{Hb} \mathrm{F})$, which in turn is eventually replaced by adult hemoglobin $(\mathrm{Hb} \mathrm{A})$. Hemoglobin $\mathrm{F}$ has a higher affinity for oxygen than $\mathrm{Hb} \mathrm{A}$, and its function is to maintain partial pressure of oxygen of fetal blood. The replacement of $\mathrm{Hb} \mathrm{F}$ with $\mathrm{Hb} \mathrm{A}$, referred as "switching," occurs within the first few weeks after birth in ruminants.

In contrast to other ruminant and European cattle breeds, the replacement of fetal erythrocytes by adult-type cells evidently does not cause a decrease in HGB and PCV after birth in the short-horn zebu calves. Whether the rise in HGB and PCV seen in these calves coincides with the switching from $\mathrm{Hb} \mathrm{F}$ to $\mathrm{Hb} \mathrm{A}$ warrants further investigation. If $\mathrm{Hb} \mathrm{F}$ replacement by $\mathrm{Hb} \mathrm{A}$ is more rapid and efficient in reaching adequate $\mathrm{Hb} \mathrm{A}$ levels before $\mathrm{Hb} \mathrm{F}$ starts declining, or if there is a delay in the decline of $\mathrm{Hb} \mathrm{F}$ while $\mathrm{Hb} \mathrm{A}$ is produced by an increasing number of adult-type erythrocytes, such that the total HGB is maintained or even increased, it would be a possible explanation for the increase

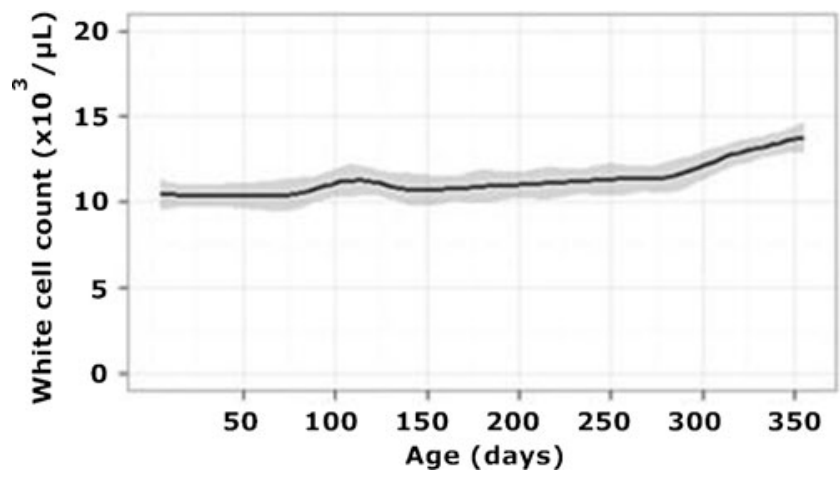

Fig. 9 Age-related changes in mean $(95 \% \mathrm{CI})$ white cell counts of East African short-horn zebu calves from birth to 51 weeks of age $(n=$ 548) 


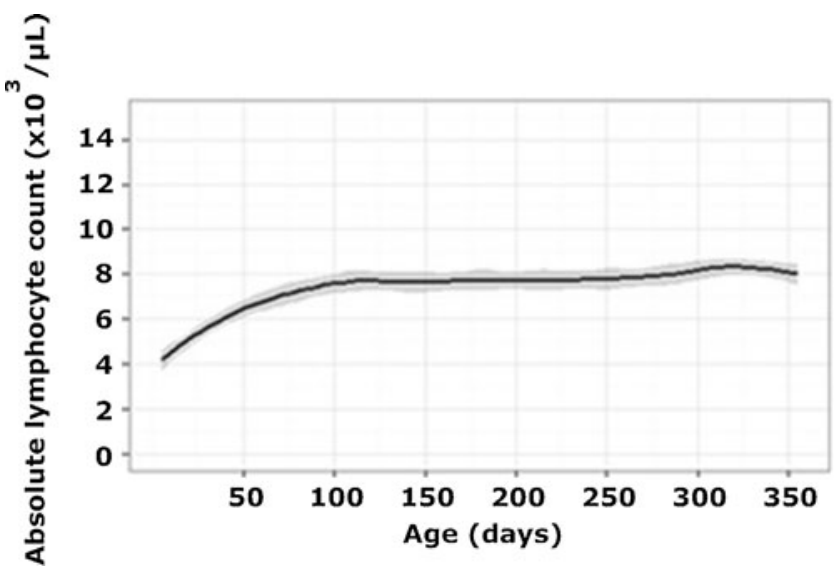

Fig. 10 Age-related changes in mean $(95 \% \mathrm{CI})$ absolute lymphocyte counts of East African short-horn zebu calves from birth to 51 weeks of age $(n=548)$

in HGB, PCV, and RCC seen during the first weeks after birth for this breed.

Prolonged postnatal production of $\mathrm{Hb} \mathrm{F}$ has been described in humans in certain hemoglobinopathies and thalassemias where production of $\mathrm{Hb} \mathrm{F}$ continues into adulthood (Pasvol et al. 1976; Nagel 1990). It is considered benign, but has been shown to be protective against malaria in early childhood by retarding the intraerythrocytic growth of Plasmodium falciparum (Pasvol et al. 1976; Nagel 1990). In areas where malaria is endemic, there is a high frequency in the genes for these hemoglobinopathies in the local human populations. Prolonged production of $\mathrm{Hb} \mathrm{F}$ in humans has also been described in neonates under hypoxic stress (Shiao and $\mathrm{Ou}$ 2006). The production of $\mathrm{Hb} \mathrm{F}$ is also pharmacologically induced in the treatment of sickle cell anemia.

Anemia is an important hematological manifestation of most endemic blood-borne diseases of cattle in the tropics, including anaplasmosis, babesiosis, and trypanosomosis. Western Kenya is an ECF endemic region, and the calves in this study were shown to be exposed to and become

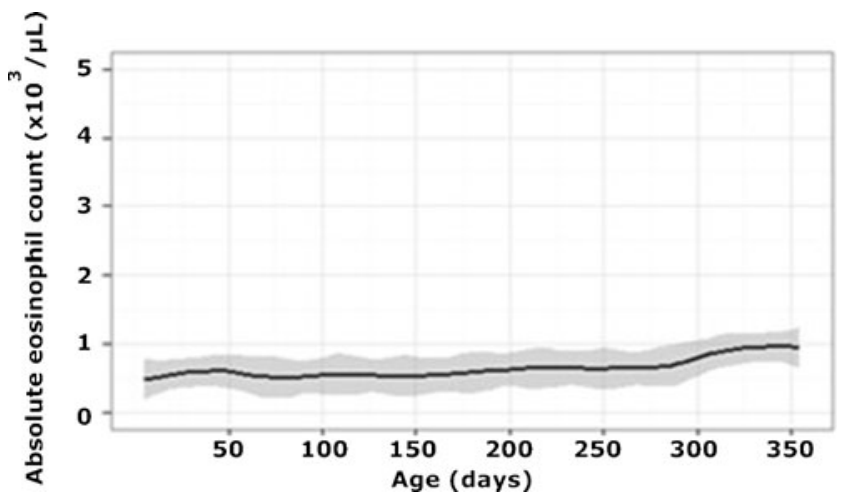

Fig. 11 Age-related changes in mean $(95 \% \mathrm{CI})$ absolute eosinophil counts of East African short-horn zebu calves from birth to 51 weeks of age $(n=548)$

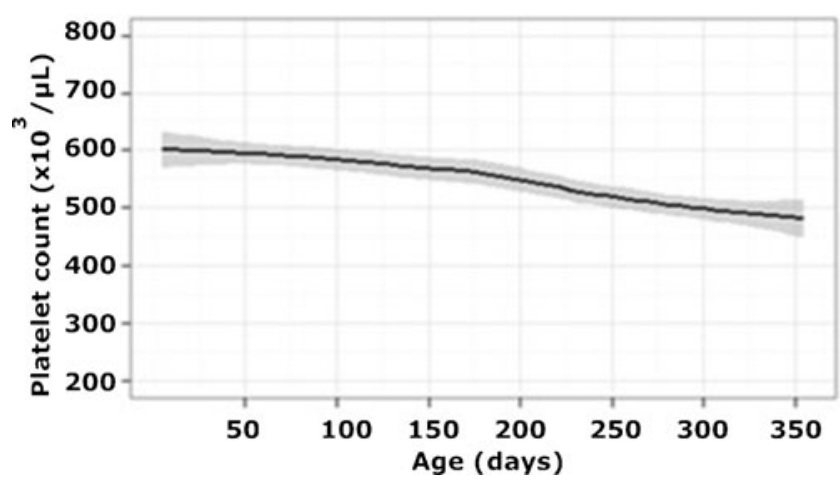

Fig. 12 Age-related changes in mean $(95 \% \mathrm{CI})$ platelet counts of East African short-horn zebu calves from birth to 51 weeks of age $(n=548)$

infected with several of the tick-borne pathogens and trypanosomes from a very early age. East African short-horn zebus are considered to be disease resistant, however, particularly against tick-borne diseases. Further diagnostic tests are required to determine whether delayed switching between hemoglobin types can explain the postnatal rise in HGB in this breed, but it makes for interesting speculation whether prolonged postnatal production of $\mathrm{Hb} \mathrm{F}$ plays any part in the innate resistance of zebu calves against bloodborne pathogens during early calfhood.

Compared to published ranges for European cattle breeds (Knowles et al. 2000; Mohri et al. 2007), TSP in these shorthorn zebu calves was considerably elevated during the entire monitoring period, but is comparable to ranges reported for other African zebu breeds (Useh et al. 2008). One possible explanation for higher TSP compared to European breeds is a high level of antigenic stimulation resulting in high globulin levels. Even from an early age, exposure to pathogens is considerable under field conditions in the tropical environment. Unfortunately only total serum proteins were investigated. Without distinguishing between different proteins, in particular albumin and the various immunoglobulins, it is difficult to come to any conclusions with regard

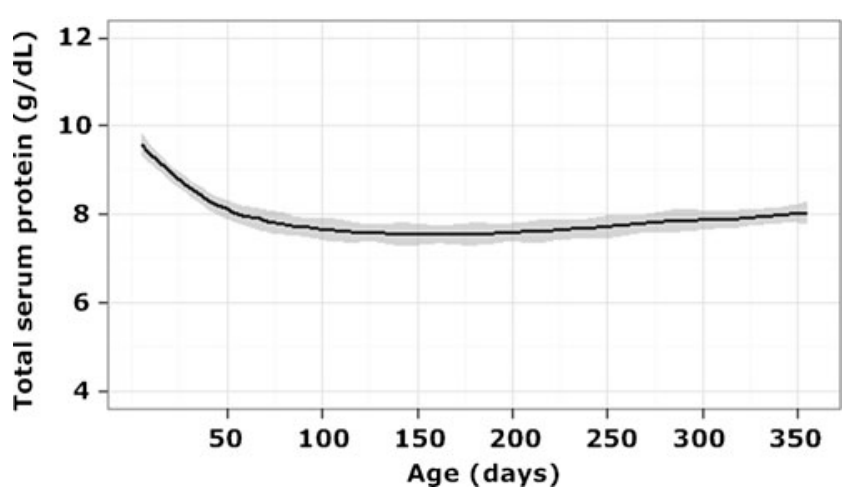

Fig. 13 Age-related changes in mean $(95 \% \mathrm{CI})$ total serum protein of East African short-horn zebu calves from birth to 51 weeks of age $(n=$ 548) 
Table 1 Reported mean packed cell volume (in percent) of various African indigenous cattle breeds

\begin{tabular}{lllll}
\hline Breed & Country & Age group & Mean PCV (\%) & Reference \\
\hline White Fulani (Zebu) & Nigeria & $0-6$ months & $30.9^{\mathrm{a}}$ & Oduye and Okunaiya (1971) \\
& & $7-12$ months & $28.5^{\mathrm{a}}$ & \\
& & $13-24$ months & $29.1^{\mathrm{a}}$ & Saror and Coles (1973) \\
White Fulani & Nigeria & Adult & $36.6 \pm 5.5(\mathrm{SD})^{\mathrm{b}}$ & Magona et al. (2008) \\
Zebu & Uganda & $0-6$ months & $24.19 \pm 1.9(95 \% \mathrm{CI})$ & \\
& & $7-12$ months & $24.2 \pm 1.5(95 \% \mathrm{CI})$ & Van den Bossche and Rowlands (2001) \\
Angoni & Zambia & Adult & $24.6 \pm 1.1(95 \% \mathrm{CI})$ & Oduye and Okunaiya (1971) \\
\hline
\end{tabular}

NS not stated

${ }^{\mathrm{a}}$ Range not reported

${ }^{\mathrm{b}}$ During wet season

${ }^{\mathrm{c}}$ Range

to the levels and trends of TSP levels in the calves in this study.

Despite its economical importance as the main cattle breed not only in Kenya, but in all of eastern Africa, little is known about baseline values of health parameters of the East African short-horn zebu. There is a need to establish breed-specific reference ranges for blood parameters for this breed. It is evident from this study that baseline values differ with age, particularly in the neonate, and possibly contributes to the physiological adaptability to environmental constraints and disease resistance of this breed. When one compares the age-related changes in the red blood cell parameters for the calves in this study to the reported values for other cattle breeds (Knowles et al. 2000;
Mohri et al. 2007), there are considerable differences in both the ranges for different age groups, as well as the trends in change over time. The reference ranges for European breeds were established in cattle in environments that are controlled for disease and nutrition. For this reason a direct comparison to the East African short-horn zebu in this study is problematic to interpret, but it is of value since the physiology of age-related changes in these breeds has been studied more extensively than in indigenous African breeds. The changes in the red blood cell parameters of the calves under study, especially during the neonatal period, are not explained by what is known about the physiology of other cattle breeds. This warrants further research into

Table 2 Reported mean packed cell volume (in percent) of various European cattle breeds

\begin{tabular}{|c|c|c|c|c|}
\hline Breed & Country & Age group & Mean PCV (\%) & Reference \\
\hline \multirow[t]{2}{*}{ Holstein } & \multirow[t]{2}{*}{ Canada } & $\begin{array}{l}1-14 \text { days } \\
2 \text { weeks to } 6 \text { months }\end{array}$ & $\begin{array}{l}\text { Range } 17-47^{\mathrm{a}} \\
\text { Range } 23-42^{\mathrm{a}}\end{array}$ & \multirow[t]{2}{*}{ Lumsden et al. (1980) } \\
\hline & & 6 months to 2 years & Range $26-48^{\mathrm{a}}$ & \\
\hline \multirow[t]{3}{*}{ Holstein } & \multirow[t]{3}{*}{ Iran } & $\begin{array}{l}1-2 \text { days } \\
4 \text { weeks }\end{array}$ & $\begin{array}{l}27 \pm 3(\mathrm{SE}) \\
24 \pm 3(\mathrm{SE})\end{array}$ & \multirow[t]{3}{*}{ Adapted from Mohri et al. (2007) } \\
\hline & & 6 weeks & $25 \pm 3(\mathrm{SE})$ & \\
\hline & & 12 weeks & $31 \pm 2(\mathrm{SE})$ & \\
\hline \multirow[t]{2}{*}{ Jersey } & \multirow[t]{2}{*}{ USA } & $\begin{array}{l}3.5-4.5 \text { months } \\
7.5-9 \text { months }\end{array}$ & $\begin{array}{l}36.16 \\
30.40\end{array}$ & \multirow[t]{2}{*}{ Jain (1993) } \\
\hline & & $11-12$ months & 28.10 & \\
\hline \multirow[t]{2}{*}{ Norwegian Red } & \multirow[t]{2}{*}{ Norway } & $\begin{array}{l}1 \text { week } \\
6-8 \text { weeks }\end{array}$ & $\begin{array}{l}\left.35^{\mathrm{a}} \text { (range } 25-39\right) \\
30^{\mathrm{a}}(\text { range } 19-37)\end{array}$ & \multirow[t]{2}{*}{ Adapted from Brun-Hansen et al. (2006) } \\
\hline & & $27-29$ weeks & $25^{\mathrm{a}}($ range $22-28)$ & \\
\hline
\end{tabular}

${ }^{\mathrm{a}}$ Hematocrit (in liters per deciliter) 
the dynamics of blood cell parameters of the East African short-horn zebu and probably other indigenous cattle breeds.

Acknowledgments The work was done as part of a the IDEAL (Infectious Diseases of East African Livestock) project, which is a collaboration between the University of Pretoria, University of Edinburgh, University of Nottingham, and the International Livestock Research Institute (ILRI), Nairobi, Kenya. We would like to thank the Kenyan Department of Veterinary Services and the animal health technicians for their logistical support, as well as the farmers who participated in this study. The IDEAL project was generously funded by the Wellcome Trust (project no. 079445). The pocH-100iV Diff automated blood analyzer was kindly sponsored by Sysmex $($ Europe GMBH. This research (project V027-09) was approved by the Research Committee of the Faculty of Veterinary Science and the Animal Use and Care Committee of the University of Pretoria.

Conflict of interest There were no conflicts of interests of any kind in the study design, collection, analysis and interpretation of data, writing of the manuscript, or the decision to submit the manuscript for publication.

\section{References}

Brun-Hansen HC, Kampen A, Lund A (2006) Hematologic values in calves during the first 6 months of life. Vet Clin Path 35:182-187

Harvey JW (1989) Erythrocyte metabolism. In: Kaneko JJ (ed) Clinical biochemistry of domestic animals, 3rd edn. Academic, San Diego, pp 185-234

Ihaka R, Gentleman R (1996) R: a language for data analysis and graphics. J Comput Graph Stat 5:299-314

Jaetzold R, Schmidt H (1983) Farm management handbook of Kenya, vol II. Natural conditions and farm management information. Ministry of Agriculture, Kenya in cooperation with the German Agricultural Team (GAT) of the German Agency for Technical Cooperation (GTZ)

Jain NC (1993) Essentials of veterinary hematology. Lea \& Febiger, Philadelphia

Karesh WB, Janssen DL, Oosterhuis JE (1986) Neonatal haematology of selected species of Cervidae and Bovidae. J Zoo An Med 17:138-146

Knowles TG, Edwards JE, Bazeley KJ, Brown SN, Butterworth A, Warriss RD (2000) Changes in the blood biochemical and haematological profile of neonatal calves with age. Vet Rec 147:593-598

Lumsden JH, Mullen K, Rowe R (1980) Hematology and biochemistry reference values for female Holstein cattle. Can J Comp Med 44:24-31

Magona JW, Walubengo JT, Odimin E (2008) Acute haemorraghic syndrome of bovine trypanosomosis in Uganda. Acta Trop 107:186-191
Maudlin I (2006) African trypanosomiasis. Ann Trop Med Parasitol 100:679-701

Minjauw B, McLeod A (2003) Tick-borne diseases and poverty. The impact of ticks and tick-borne diseases on the livelihood of smallscale and marginal livestock owners in India and eastern and southern Africa. Research report, DFID (Department for International Development) Animal Health Programme, Centre for Tropical Veterinary Medicine, University of Edinburgh, UK

Mohri M, Sarrafzadeh F, Seifi A, Farzaneh N (2004) Effects of oral iron supplementation on some haematological parameters and iron biochemistry in neonatal dairy calves. Comp Clin Path 13:39-42

Mohri M, Sharifi K, Eidi S (2007) Hematology and serum biochemistry of Holstein dairy calves: age related changes and comparison with blood composition in adults. Res Vet Sci 83:30-39

Mwacharo JM, Drucker AG (2005) Production objectives and management strategies of livestock keepers in south-east Kenya: implications for a breeding programme. Trop Anim Health Prod 37:635-652

Mwacharo JM, Okeyo AM, Kamande GK, Rege JEO (2006) The small East African Shorthorn zebu cows in Kenya I: linear body measurements. Trop Anim Health Prod 38:65-74. doi:10.1007/ s11250-006-4266-y

Nagel RL (1990) Innate resistance to malaria: the intraerythrocytic cycle. Blood Cells 16:321-339

Oduye OO, Okunaiya OA (1971) Haematological studies on the white Fulani and N'Dama breeds of cattle. Bull Epizoot Dis Afr 19:213-218

Pasvol G, Weatherall DJ, Wilson RJ, Smith DH, Gilles HM (1976) Fetal haemoglobin and malaria. Lancet 12:1269-1272

Perry BD, Young AS (1995) The past and future roles of epidemiology and economics in the control of tick-borne diseases of livestock in Africa: the case of theileriosis. Prev Vet Med 25:107-120

Rege JEO, Kahi AK, Okomo-Adhiambo M, Mwacharo J, Hanotte O (2001) Zebu cattle of Kenya: uses, performance, farmer preferences, measures of genetic diversity and options for improved use. Animal Genetic Resources Research 1 International Livestock Research Institute, Nairobi. http://www.ilri.org/InfoServ/ Webpub/fulldocs/AnGenResCD/docs/Zebucattle/. Accessed 14 Jan 2012

Saror D, Coles EH (1973) The blood picture of white Fulani (Zebu) and white Fulani/Friesian (crossbred) dairy cows. Bull Epizoot Dis Afr 21:485-487

Shiao SYP, Ou CN (2006) Accurate measurements of fetal haemoglobin for neonates with different gestational ages. Hemoglobin 30:419-435

Uilenberg G (1995) International collaborative research: significance of tick-borne hemoparasitic diseases to world animal health. Vet Parasitol 57:19-41

Useh NM, Nok AJ, Ibrahim NDG, Adamu S, Esievo KAN (2008) Haematological and some novel biochemical changes in Zebu cattle with blackleg. Bulg J Vet Med 11:205-211

Van den Bossche P, Rowlands GJ (2001) The relationship between the parasitological prevalence of trypanosomal infections in cattle and herd average packed cell volume. Acta Trop 78:163-170 